PERM JOURNAL OF PETROLEUM AND MINING ENGINEERING

ВЕСТНИК ПНИПУ. ГЕОЛОГИЯ. НЕФТЕГАЗОВОЕ И ГОРНОЕ ДЕ ЛО

ISSN 2224-9923

Volume / Tом 20 №2, 2020

http://vestnik.pstu.ru/gec

UDC 622.276.652(470.13)

Article / Статья

(c) PNRPU / ПНИПУ, 2020

\title{
EFFICIENCY IMPROVEMENT OF THE CYCLIC STEAM TREATMENT \\ OF WELLS IN THE UPPER PERMIAN DEPOSIT OF THE USINSKOYE FIELD BASED ON THE HYDRODYNAMIC MODEL
}

\author{
Maksim B. Savchik, Daria V. Ganeeva, Aleksei V. Raspopov
}

PermNIPIneft branch of LUKOIL-Engineering LLC in Perm (3a Permskaya st., Perm, 614015, Russian Federation)

\section{ПОВЫШЕНИЕ ЭФФЕКТИВНОСТИ ПАРОЦИКЛИЧЕСКИХ ОБРАБОТОК СКВАЖИН ВЕРХНЕПЕРМСКОЙ ЗАЛЕЖИ УСИНСКОГО МЕСТОРОЖДЕНИЯ НА ОСНОВЕ ГИДРОДИНАМИЧЕСКОЙ МОДЕЛИ}

\section{М.Б. Савчик, Д.В. Ганеева, А.В. Распопов}

Филиал ООО «ЛУКОЙЛ-Инжиниринг» «ПермНИПИнефть» в г. Перми (614015, Россия, г. Пермь, ул. Пермская, 3а)

Received / Получена: 17.02.2020. Accepted / Принята: 15.04.2020. Published / Опубликована: 15.06.2020

\section{Key words}

efficiency improvement, oil deposit, high viscosity oil, hydrodynamic model, modeling, simulator, cyclic steam treatment, thermal methods, thermal treatment, optimum process parameters, steam injection, soaking, production, heating, optimization, formation oil recovery, profitability.

\begin{abstract}
Development of the Upper Permian high viscosity oil deposit is expected to involve thermal methods of enhanced oil recovery, in particular, cyclic steam treatment of wells

The simulator used for the deposit modeling is to be capable of computing the change in the rock fluid thermal properties, and of solving the heat and mass transfer equations. The modeling of the cyclic steam treatments used CMG STARS, a numerical simulator with a wide range of applications including modeling of thermal processes.

The cyclic steam treatment includes three basic stages, such as the steam injection period, the soak period, and the production period. The number of cycles has been selected by computation on the basis of an optimum well operation. To determine the optimum quantity, computations with 7, 5 and 3 cycles were performed. Another predictive computation was performed for a well operation without cyclic steam treatments. The computations helped to determine the operation scenario with the highest cumulative oil production.

During the assessment of the cyclic steam treatment efficiency by using hydrodynamic modeling, we obtained dependencies on a number of geological and physical factors, such as steam dryness fraction, formation thickness, steam injection rate, soaking time.

The numerical experiments resulted in conclusions and recommendations concerning the case-by-case approach to selecting optimum parameters of the cyclic steam treatments for each individual well, taking into account the structure and specific features. optimum parameters of the cyclic steam treatments for each individual well, taking into account the structure and specific features.
Factor analysis was used to select the optimum parameters for the cyclic steam treatment of the wells drilled in the Upper Permian Factor analysis was used to select the optimum parameters for the cyclic steam treatment of the wells drilled in the
deposit of the Usinskoye field. For comparison, three predictive scenarios of the well operation have been computed. deposit of the Usinskoye field. For comparison, three predictive scenarios of the well operation have been computed.
Cost-performance indicators of the well operation scenarios in the Upper Permian deposit of the Usinskoye field were evaluated, assuming that the wells will be operated in conditions of the natural recovery drive and multiple cyclic steam treatments, in the baseline and recommended scenarios.
\end{abstract} увеличения нефтеотдачи - пароциклических обработок скважин.

При моделировании залежи должен использоваться симулятор, который позволяет рассчитывать изменения тепловых свойств флюидов породы, а также решать уравнения тепломассопереноса. Моделирование пароциклических обработок производилось в CMG STARS - это численный симулятор обширного спектра применения, в том числе он может использоваться и для моделирования тепловых процессов.

Пароциклическая обработка проходит в три основных стадии: период закачки пара; период выдержки; период добычи.

Расчетным путем осуществлен подбор количества циклов на основе оптимальной работы скважины. Для определения оптимального количества проведены расчеты с 7, 5 и 3 циклами. Также выполнен прогнозный расчет работы скважины без пароциклических обработок. По результатам расчета выявлен режим с наибольшей накопленной добычей нефти.

При оценке эффективности пароциклических обработок скважин при помощи гидродинамического моделирования получены зависимости от ряда геолого-физических параметров, таких как степень сухости пара, толщина пласта, темп закачки пара, продолжительность пропитки.

По результатам численных экспериментов сделаны выводы и даны рекомендации по индивидуальным подходам к выбору оптимальных параметров пароциклических обработок для каждой отдельной скважины, с учетом ее строения и особенностей.

С помощью факторного анализа выбраны наиболее оптимальные параметры для пароциклической обработки скважин верхнепермской залежи Усинского месторождения. В качестве сравнения рассчитано три прогнозных варианта работы скважины.

Выполнена оценка технико-экономических показателей эффективности вариантов эксплуатации скважин верхнепермской залежи Усинского месторождения, предусматривающих работу скважин в условиях естественного режима и проведение многократных пароциклических обработок при базовом и рекомендуемом вариантах.

\footnotetext{
Maksim B. Savchik (Scopus ID 49964275000) - Lead Engineer of the Division for the Creation and Monitoring of Hydrodynamic models (tel.: +0073422353105 , e-mail: maksim.Savchik@pnn.lukoil.com). The contact person for correspondence.

Daria V. Ganeeva $-1^{\text {st }}$ category Engineer of the Division for the Creation and Monitoring of hydrodynamic models (tel.: +007 342 233 78 86, e-mail: Darya.Ganeeva@pnn.lukoil.com). Aleksei V. Raspopov (Scopus ID 30267829600) - PhD in Engineering, Deputy Director of the Branch for Scientific Work in the Area of Field Development (tel.: +007 34221982 92, e-mail: aleksej.raspopov@pnn.lukoil.com).

Савчик Максим Брониславович - ведущий инженер отдела создания и мониторинга гидродинамических моделей (тел.: +007 3422353105 , e-mail: maksim.Savchik@pnn.lukoil.com). Контактное лицо для переписки.

Ганеева Дарья Владимировна - инженер 1-й категории отдела создания и мониторинга гидродинамических моделей (тел.: +007 34223378 86, e-mail: Darya.Ganeeva@pnn.lukoil.com).

Распопов Алексей Владимирович - кандидат технических наук, заместитель директора филиала по научной работе в области разработки месторождений (тел.: +007 34221982 92, e-mail: aleksej.raspopov@pnn.lukoil.com).
} 


\section{Introduction}

A significant part of geological reserves in the fields of the Komi Republic is represented by high viscosity oil. Efficient recoveries of these reserves are possible through implementation of thermal methods for an enhanced oil recovery. Cyclic steam treatment $(\mathrm{CST})$ is an effective method intended for thermal treatment of productive strata. The method has been successfully piloted at the Permo-Carboniferous deposit of the Usinskoye field and at the deposit of the Asselian-Sakmarian sequence of the Osvanjurskoye field. However, taking into account high cost of this type of treatment (cost of stationary steam generators (SG), their installation and connection, injection wellhead connection, construction of project wells), the operations have to be planned reasonably, including a justified choice of candidate wells for treatment and optimization of the operation parameters (a number of treatment cycles, steam dryness fraction, steam injection rate, soaking time etc.). This problem can be solved using the geological hydrodynamic model.

The provided results justify the planning stage of the cyclic steam treatments of the high viscosity oil wells in the Upper Permian deposit (P2u-IV) of the Usinskoye field using the geological hydrodynamic model.

\section{Input Data}

The process of creating a three-dimensional digital hydrodynamic model consists of a series of successive steps with typical methods, procedures and intermediate results.

A three-dimensional geological modeling of the Usinskoye field oil deposits was implemented using IRAP RMS software suite by ROXAR. The input data for modeling of petrophysical parameters consisted of the results of the stratum-by-stratum interpretation of data obtained from geoinformation systems (GIS) - porosity, permeability and oil saturation curves. Determination of porosity, permeability and oil saturation ratios was only performed in formations. Modeling in the impermeable part of the section was not performed.

In order to preserve the geological inhomogeneity of the Upper Permian deposits of the Usinskoye field, the procedure of transition from the detailed geological model to the more generic hydrodynamic model (rescaling) was not performed.

The isothermal model of the two-phase threecomponent filtration of dead oil was selected as the hydrodynamic model of P2u-IV object. The choice was based on such factors as absence of free gas, absence of gas injection, and the condition that throughout the entire history matching period, the development was conducted at the formation pressure exceeding the saturation pressure.

Modeling of P2u-IV deposit development involved creation of an isothermal Black Oil model in the format of IMEXCMG simulator. Thermal methods of the oil recovery enhancement will be used for the deposit development. Thus, the simulator used as a computation module is to be capable of computing the change in the rock fluid thermal properties, and of solving the heat and mass transfer equations. CMG STARS simulator of thermal (non-isothermal) and special processes fully meets these requirements.

The modeling involved normalization of basic dependencies of relative phase permeabilities (RPP), as well as modification of RPP curve shape on the basis of actual water flooding dynamics of the producing wells. Capillary pressure curves were not modified.

In the hydrodynamic model, the history match took into account the operation results for nine wells. The history matching task was to reproduce the development history since 1986 (32 years).

The following input data were used [1]:

- well trajectories, coordinates of well bottoms and intersections according to the field's geological model;

- dynamics of oil, water and liquid outputs from the database according to the monthly and yearly reporting, from the beginning of development as of January $1^{\text {st }}$, 2019

- dynamics of the well perforation and isolation intervals, and well interventions;

- results of the production well logging;

- dynamics of formation and bottom-hole pressures by wells, obtained from hydrodynamic tests of the wells.

The appearance and section of P2u-IV formation hydrodynamic model exemplified by the oil saturation cube are shown in Fig. 1.

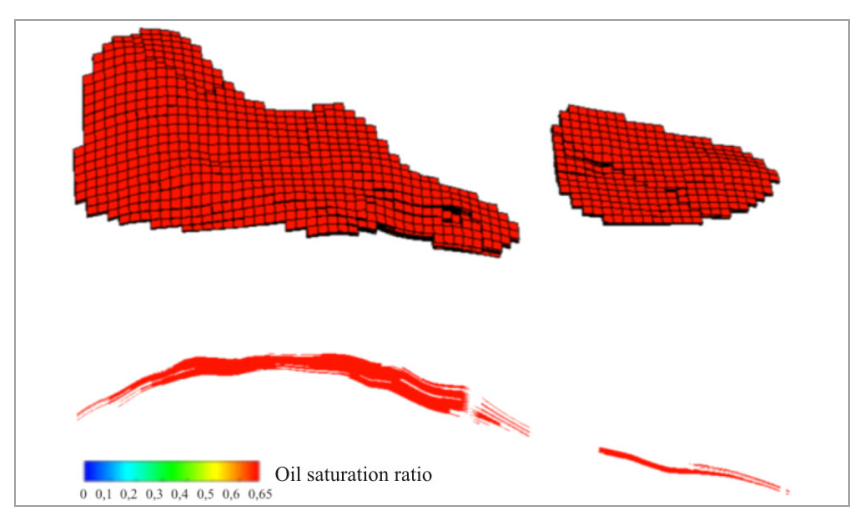

Fig. 1. Appearance and section of $\mathrm{P} 2 \mathrm{u}-\mathrm{IV}$ formation hydrodynamic model exemplified by the oil saturation cube 


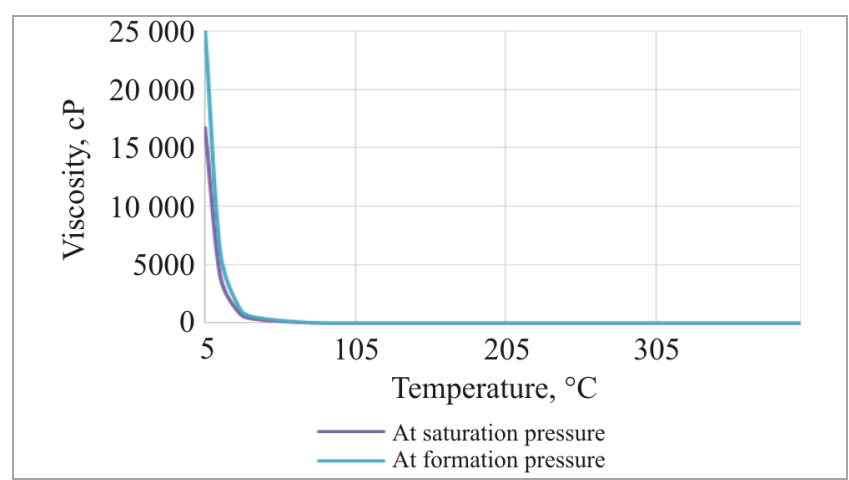

Fig. 2. Dependency of oil viscosity on temperature

Table 1

Input data for CST modeling

\begin{tabular}{|c|c|}
\hline Parameter & Indicator \\
\hline \multicolumn{2}{|l|}{ Formation properties } \\
\hline Thickness, $\mathrm{m}$ & $12(9-14)$ \\
\hline Horizontal permeability, $\mu \mathrm{m}^{2}$ & 0.760 \\
\hline Porosity, \% & 25.6 \\
\hline Bulk elasticity, $1 / \mathrm{kPa}$ & $5.8 \cdot 10^{-5}$ \\
\hline Thermal conductivity, $\mathrm{J} /\left(\mathrm{m} \cdot \mathrm{day} \cdot{ }^{\circ} \mathrm{C}\right)$ & $2.16 \cdot 10^{5}$ \\
\hline Heat capacity, $\mathrm{J} /\left(\mathrm{m}^{3} \cdot{ }^{\circ} \mathrm{C}\right)$ & $3.35 \cdot 10^{6}$ \\
\hline \multicolumn{2}{|l|}{ Enclosing rock properties } \\
\hline Thermal conductivity, $\mathrm{J} /\left(\mathrm{m} \cdot \mathrm{day} \cdot{ }^{\circ} \mathrm{C}\right)$ & $2.16 \cdot 10^{5}$ \\
\hline Heat capacity, $\mathrm{J} /\left(\mathrm{m}^{3} \cdot{ }^{\circ} \mathrm{C}\right)$ & $3.35 \cdot 10^{6}$ \\
\hline \multicolumn{2}{|l|}{ Oil properties } \\
\hline Model type & "Dead" oil \\
\hline Molecular weight, $\mathrm{kg} / \mathrm{gmol}$ & 0.455 \\
\hline Density in formation conditions, $\mathrm{kg} / \mathrm{m}^{3}$ & 913.0 \\
\hline Viscosity in formation conditions, $\mathrm{mPa} \cdot \mathrm{s}$ & 242.3 \\
\hline Saturation pressure, $\mathrm{MPa}$ & 3.6 \\
\hline Gas-oil ratio, $\mathrm{m}^{3} / \mathrm{t}$ & 12 \\
\hline Formation volume factor & 1.031 \\
\hline Bulk elasticity, $1 / \mathrm{kPa}$ & $5.8 \cdot 10^{7}$ \\
\hline Thermal expansion, $1 /{ }^{\circ} \mathrm{C}$ & $6.84 \cdot 10^{-4}$ \\
\hline Thermal conductivity, $\mathrm{J} /\left(\mathrm{m} \cdot\right.$ day $\left.\cdot{ }^{\circ} \mathrm{C}\right)$ & $1.495 \cdot 10^{5}$ \\
\hline Heat capacity, $\mathrm{J} /\left(\mathrm{m}^{3} \cdot{ }^{\circ} \mathrm{C}\right)$ & 1.15 \\
\hline \multicolumn{2}{|l|}{$\begin{array}{l}\text { Formation conditions } \\
\end{array}$} \\
\hline Pressure, $\mathrm{MPa}$ & 11.6 \\
\hline Temperature, ${ }^{\circ} \mathrm{C}$ & 20 \\
\hline Oil saturation & 0.61 \\
\hline
\end{tabular}

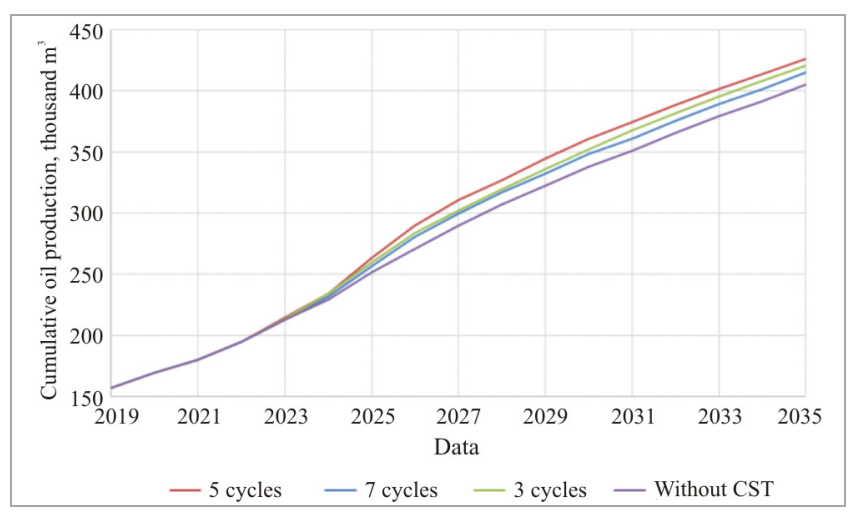

Fig. 3. Cumulative oil production computed with $3,5,7$ cycles and without cyclic steam treatment
The hydrodynamic model of object P2u-IV was based on dependencies of viscosity on temperature, thermal properties of formation, oil and water by analogy with those of the Permo-Carboniferous deposit of the Usinskoye field. The dependency of viscosity on temperature is shown in Fig. 2.

The input data for modeling of well CST in CMG STARS software module are provided in Table 1.

\section{Well CST Process Modeling}

CST modeling was performed using CMG STARS software module which can simulate compositional, thermal, geomechanical (fracturing, compaction, caving of rock) processes in presence of disperse components (polymers, gels, rock particles, emulsions, foams) or without them, and interbedding combustion process.

The development of the Upper Permian high viscosity oil deposit is expected to include thermal methods of enhanced oil recovery, specifically CST. CST modeling was performed on 9 wells, 4 out of which were active producing wells (treatments starting from 2022), reactivation of one well in 2022, transitions from the underlying object for one well from 20222024 , one project producing well in 2024 , according to the project document [2].

Cyclic steam treatment undergoes three basic stages, such as the steam injection period, the soak period, and the production period.

The selection of a number of cycles was performed by computation on the basis of optimum well operations. In order to determine the optimum number, computations with 7,5 and 3 cycles were performed. The predictive computation of the well operation without cyclic steam treatments was also performed. According to the computation results, the highest cumulative oil production corresponds to 5 CST cycles (Fig. 3).

If the number of treatments is higher, the steam injected into the well does not have enough time to soak in and heat up the near-wellbore area. Further production in the well will require withdrawal of water condensate prior to obtaining a small increment in oil output.

The well operation output is assumed as the minimum profitable output to be achieved for implementation of an injection cycle (Fig. 4).

Fig. 5 shows CST stages and the extent of the oil viscosity change as a function of the formation temperature increase in well No. 1000 region.

\section{Factor Analysis of CST Efficiency}

During the assessment of the cyclic steam treatment efficiency using hydrodynamic modeling, dependencies on a number of geological and physical factors were 


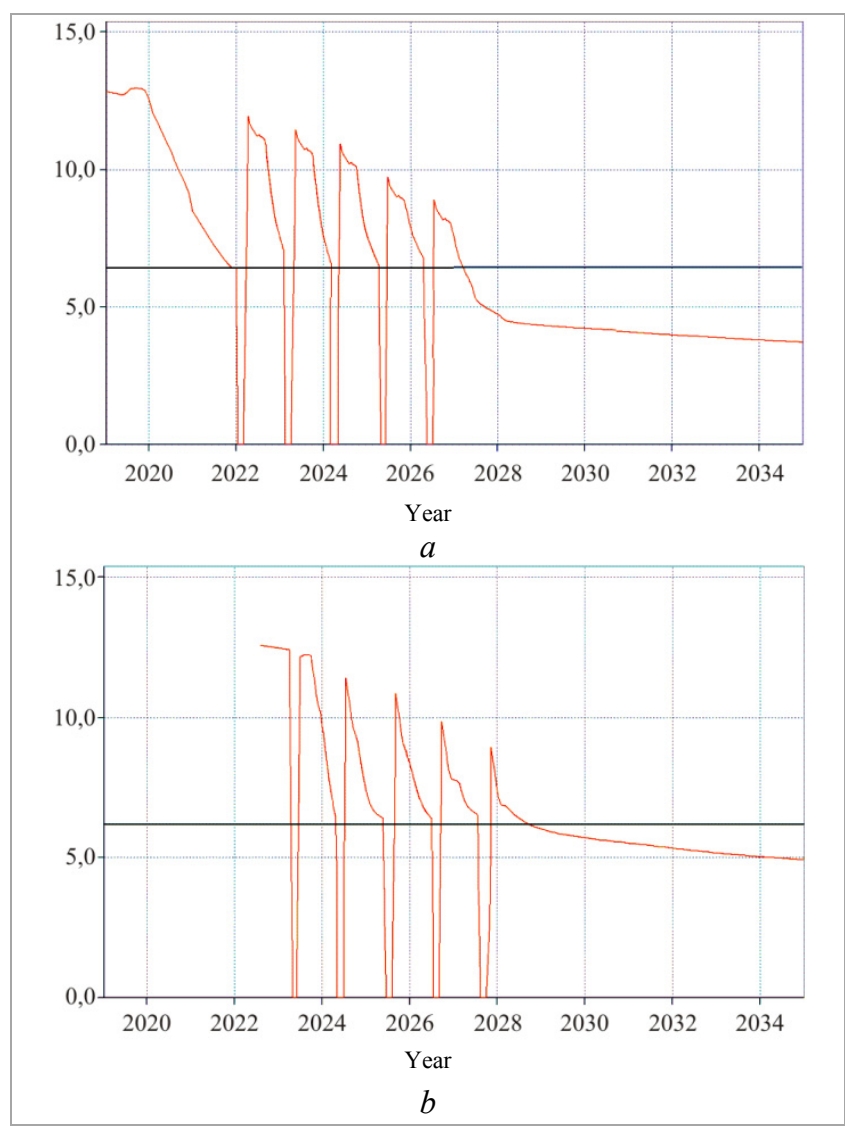

Fig. 4. Oil withdrawal curve at 5 cycles: operating well No. $1000(a)$ and project well No. $43(b)$ obtained, such as steam dryness fraction, formation thickness, steam injection rate, soaking time [3-8].

Impact of steam dryness fraction. Four steam dryness fraction values were considered (50, 70, $90 \%$ and $0 \%$ is hot water) at the same steam injection rate. The computation results are shown in Fig. $6(a)$.

The obtained data suggests that an increase in steam dryness is associated with an increase in oil production. If the steam dryness fraction increases at a constant injection rate, heat is injected in the well, which results in an increase of the heated-up area of the formation and thus, the amount of heated oil.

Mean formation temperature increases during the injection stage and later decreases following the same trend during the stage of soaking and production at all considered steam dryness fraction values. The temperature difference is caused by gradual commissioning of the wells and their cyclic steam treatments.

Owing to the latent heat of evaporation, water steam has a substantially larger heat content than hot water [9-12].

Impact of formation thickness. Three formation thickness scenarios were considered $(9,12$ and $14 \mathrm{~m})$ with all other parameters unchanged. The computation results are shown in Fig. $6, b$.

As the formation thickness grows, the cumulative oil and water production decreases due to the decrease in the ratio of the heated formation volume to its overall volume.

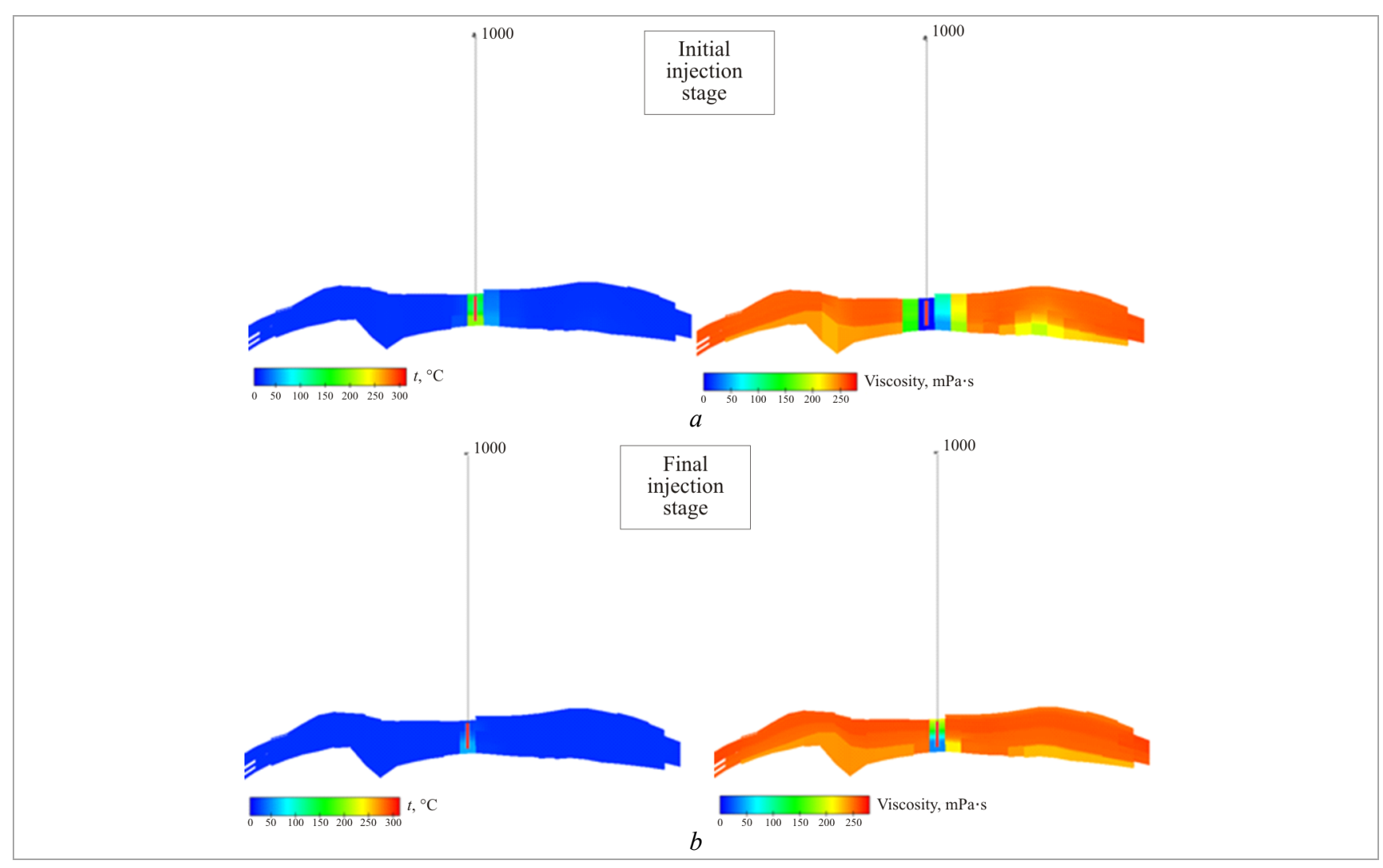

Fig. 5. Hydrodynamic model section for well No. 1000 exemplified by cubes of oil temperature (a) and viscosity $(b)$ 


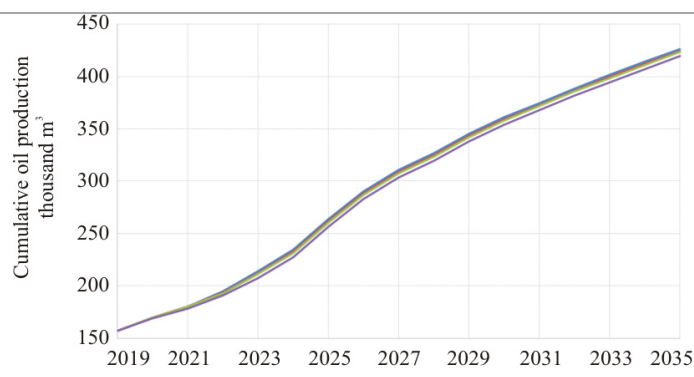

$-90 \%-70 \%-50 \%-0 \%$

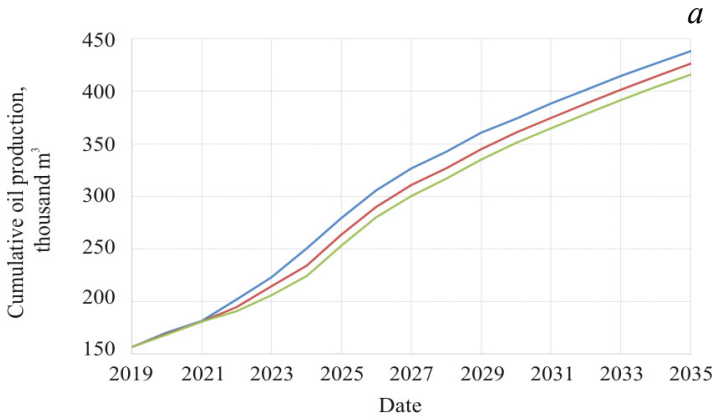
$-9 \mathrm{~m}-12 \mathrm{~m}-14 \mathrm{~m}$

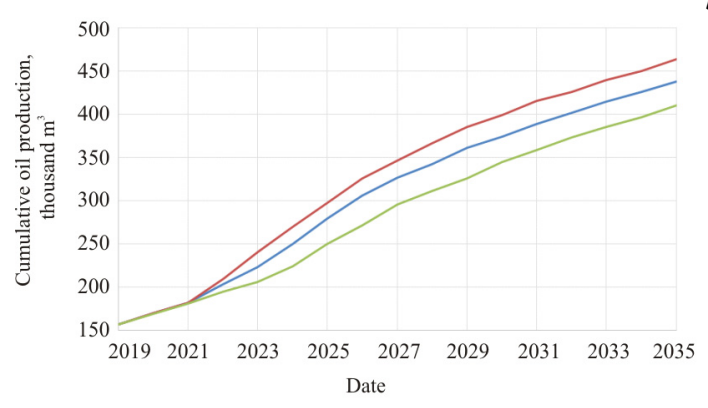

$$
-50 \mathrm{~m}^{3} / \text { day }-75 \mathrm{~m}^{3} / \mathrm{day}-30 \mathrm{~m}^{3} / \text { day }
$$

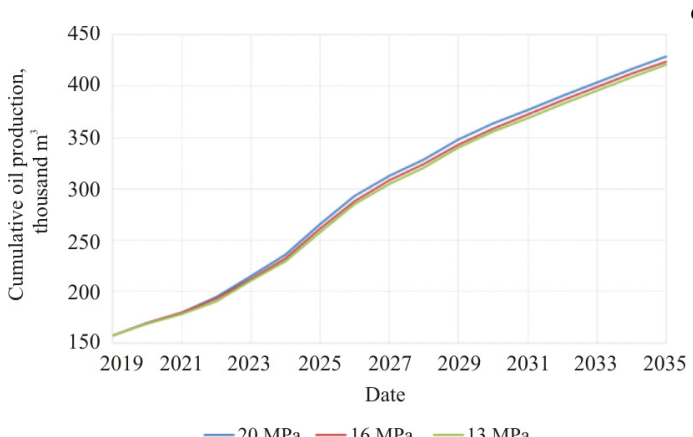

$$
-20 \mathrm{MPa}-16 \mathrm{MPa}-13 \mathrm{MPa}
$$

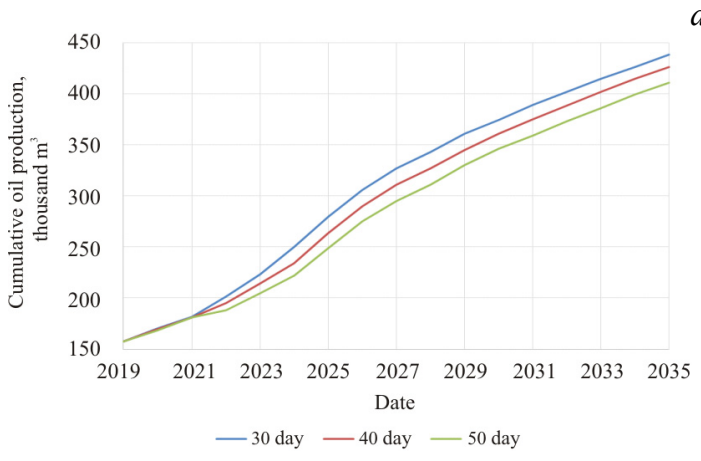

$$
-30 \text { day }-40 \text { day }-50 \text { day }
$$

Fig. 6. Dependence of cumulative oil production and formation temperature: $a$ - on steam dryness fraction; $b$ - on formation thickness; $c$ - on steam injection rate; $d$-on steam injection pressure; $e$ - on soak time
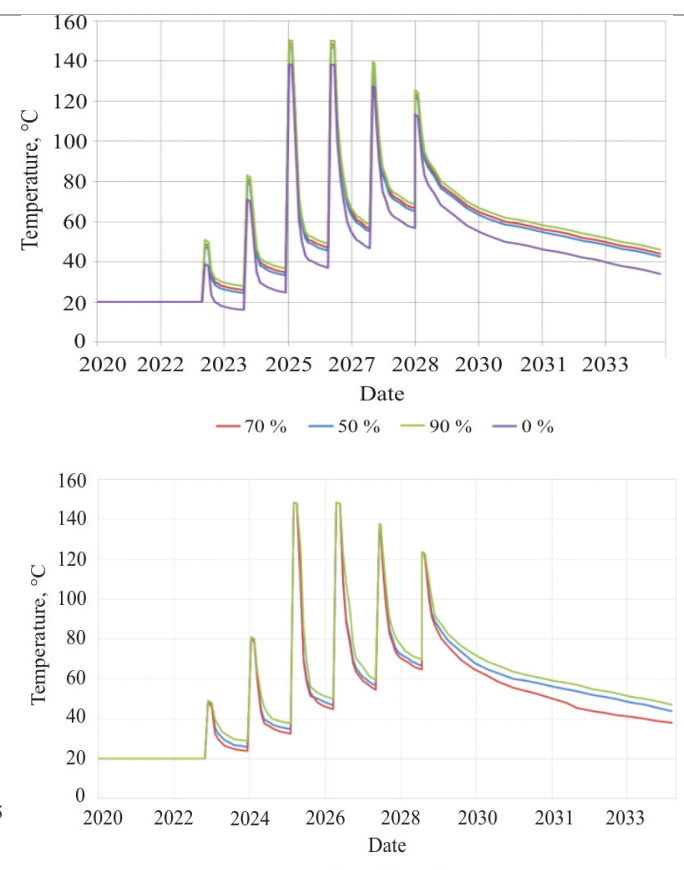

b
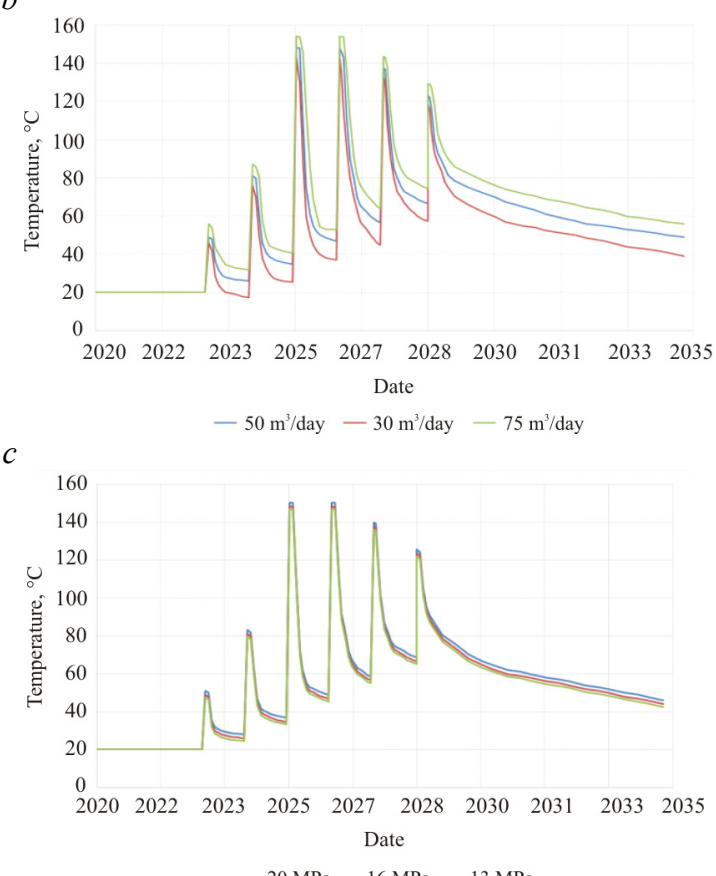

$d$

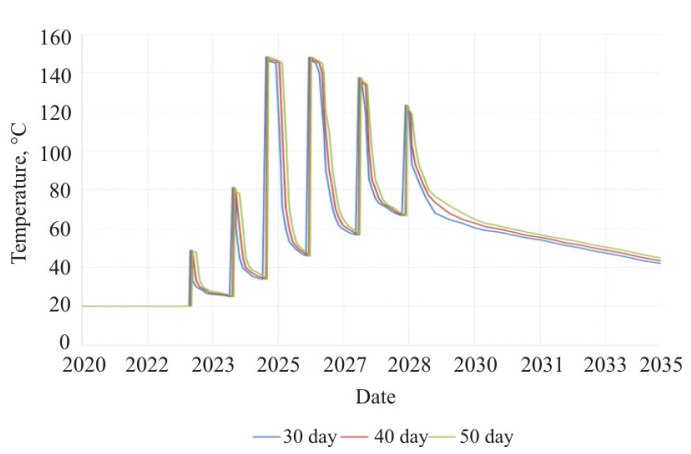


Bottom-hole temperature decreases faster for thinner formations. The thinner the formation, the higher the amount of the heat loss to the overlying enclosing rock, and the higher the temperature gradient $[13,14]$.

Impact of steam injection rate. Three specific steam injection rate scenarios were considered, e.g. 30,50 and $75 \mathrm{~m}^{3} /$ day. The data shown in Fig. 6, $c$, suggests that oil production grows significantly when the steam injection rate increases, since more heat and steam condensate is injected into the formation, which also leads to an increase of the heated-up formation volume [15-20].

The increased steam injection rate causes a decrease in the temperature drop per cycle. This dynamics reflects the fact that the higher steam injection rate brings more thermal energy to the formation, which slowly dissipates into the formation and enclosing rock $[11,12]$.

Impact of steam injection pressure. Three injection pressure scenarios were considered (13, 16.5 and $20 \mathrm{MPa})$. The computation results are shown in Fig. 6, $d$.

As can be seen from the obtained data, the increasing injection pressure caused an increase in the injected steam temperature at a constant injection rate and steam dryness fraction. A certain increase in the cumulative oil and water production is noted, as the steam injection pressure grows. However, the discovered effect appears to be negligible due to the stability of other contributing variables. As the bottom hole pressure grows, the latent heat of vaporization goes down, which decreases the overall amount of heat injected into the well and increases the heat loss to the enclosing rock, which depends rather on temperature than on the quantity of the injected heat. A higher formation temperature stimulated a higher oil production output in the well, so more heat was lost with the produced fluid at the initial stage of production [21-26].

Impact of soak duration. Three soak duration interval values were considered $-20,30$ and 40 days [27-32]. The obtained results are shown in Fig. 6,e.

\section{Conclusions of the Numerical Experiments}

The following conclusions have been made on the basis of the summarized data. First of all, the increase of the steam dryness fraction leads to the oil production growth, since it is associated with an increase of heat quantity per unit of the formation volume, because a large portion of thermal energy is injected as the latent heat of vaporization. Each volume unit of the injected steam contains more heat due to the presence of the latent heat, which leads to a higher oil output. Therefore, in order to increase oil output, it is recommended to use steam with a higher dryness fraction [33-35]. Secondly, the thermal energy density decreases for thicker formations. This is because more volume of the formation contacts the steam. Thus, an excessive formation thickness can lead to low oil output growth rates, since the heat density in such formations is extremely high, which leads to large heat losses in the enclosing rock [36-39]. Thirdly, a high steam injection rate facilitates the delivery of more heat to the formation and increases oil production. However, a very high steam injection rate can lead to the formation overheating, which, in turn, can cause large heat losses and reduce thermal efficiency of the process. An optimum steam injection rate helps to decrease heat losses and maximize the steam chamber volume $[40,41]$. Also, the bottom hole pressure increase has a negligible effect on oil production, since the latent heat of vaporization decreases. The overall heat amount added by the steam to the formation increases insignificantly too [42, 43]. Finally, the efficiency of the cyclic steam treatment of the horizontal wells is improved by reducing the soak period duration, since it improves the thermal efficiency of multiple CST process due to better use of the injected heat [44].

Notably, the most efficient approach consists in a case-by-case selection of optimum CST parameters for each individual well, taking into account its structure and specific features $[45,46]$.

\section{Predictive Computations}

Based on the factor analysis results, the most optimum parameters for CST process were selected. For comparison, three predictive scenarios of the well operation were computed. Scenario 1 includes the process parameters defined in the industrial engineering documentation and based on the process in wells of similar fields. Scenario 2 includes the process implementation with parameters selected in the previous chapter of this work. The baseline scenario is the prediction of well operation dynamics without thermal treatments.

The process parameters for the basic and recommended CST scenarios are shown in Table 2.

Fig. 7 shows cumulative production curves for each scenario demonstrating that the selected parameters ensure a significant oil production increase for the well.

Therefore, according to the performed computations, five CST cycles with parameters shown in Table 2 are optimal for the Upper Permian deposit.

The comparison of the obtained results in the recommended scenario with the basic scenario of 
Table 2

Process parameters for the basic and recommended well CST scenarios

\begin{tabular}{|c|c|c|}
\hline Parameter & Basic & Recommended \\
\hline Number of CST cycles & & 5 \\
\hline \multicolumn{3}{|c|}{ Injection period } \\
\hline Working medium & Steam & Steam \\
\hline Maximum injection pressure, $\mathrm{MPa}$ & 15.0 & 20.0 \\
\hline Maximum injection rate, $\mathrm{m}^{3} /$ day & 40.0 & 50.0 \\
\hline Steam dryness fraction, $\%$ & 70.0 & 90.0 \\
\hline Injection time, days & 30.0 & 30.0 \\
\hline \multicolumn{3}{|c|}{ Soak period } \\
\hline Soak time, days & 30.0 & 30.0 \\
\hline \multicolumn{3}{|c|}{ Production period } \\
\hline Minimum bottom hole pressure, $\mathrm{MPa}$ & 3.6 & 3.6 \\
\hline $\begin{array}{l}\text { Maximum liquid withdrawal rate, } \\
\mathrm{m}^{3} / \text { day }\end{array}$ & 110.0 & 110.0 \\
\hline Production time, days & 330 & 330 \\
\hline
\end{tabular}

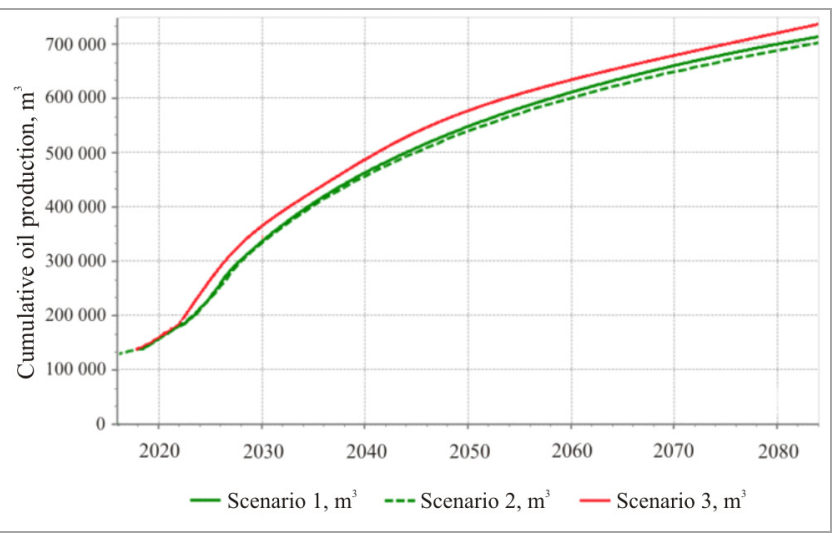

Fig. 7. Oil production dynamics comparison for the three scenarios

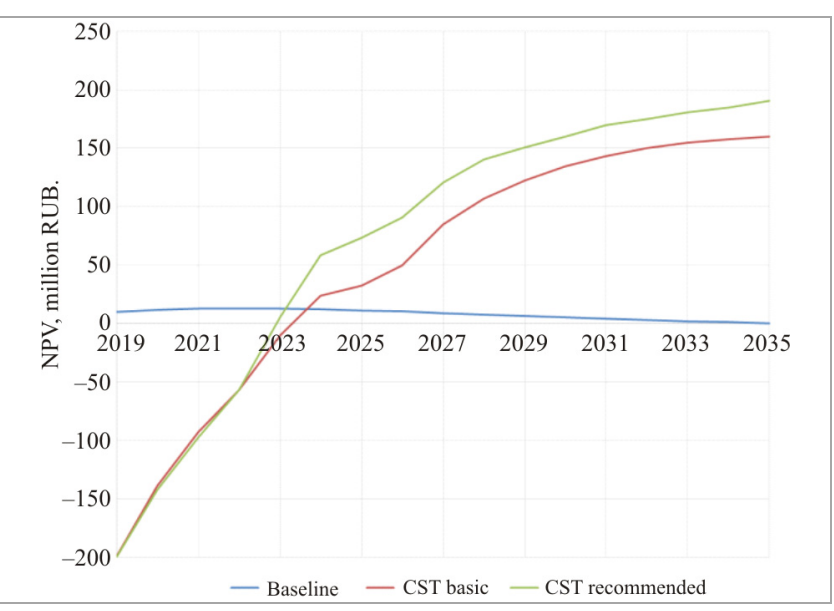

Fig. 8. Net present value for the three prediction scenarios

treatment and the well operation without treatment shows that the performance of five well CST cycles in an optimum mode ensures an increase in the cumulative oil production. In the scenario of CST with the basic parameters for 17 years (2035) of the predictive computation, the cumulative production is $5 \%$ higher.

\section{Computation of Key Cost Indicators}

The main objective of the computations is to estimate the cost-performance indicators for the well operation scenarios in the Upper Permian deposit of the Usinskoye field. The scenarios under consideration are natural recovery drive and multiple cyclic steam treatments (basic and recommended scenarios).

The costs of an oilfield development for the scenario with CST includes the cost of stationary steam generators, their installation and connection, connection of injection well heads, and construction cost of project wells.

Operational costs include critical direct cost items, such as production and injection of steam (for CST of wells), electricity, oil treatment, oil collection, transportation, and salary. Fig. 8 shows the net present value diagram.

Table 3 shows the net present value magnitudes for the recommended CST scenario, CST scenario with the basic parameters and the baseline scenario of the well operation with the natural recovery drive over the period of 17 years.

Table 4 shows basic parameters of the cost computation.

The payback period amounted to 4 years for the recommended scenario with the capital investment of RUB 676.6 million and operating costs of RUB 546.3 million. For other scenarios, the payback period amounted to approximately 5 years.

The sensitivity diagram (Fig. 9) shows the dependence between the net profit and basic parameters, such as price of oil, capital and operating costs. The dependence takes into account NPV change in the recommended predicted scenario from the twenty-percent variance of the basic cost indicators. As it can be seen from the sensitivity diagram, if oil prices, capital and operating costs change by $20 \%$, the oil price is the most significant parameter.

\section{Conclusion}

The study analyzed the efficiency of the cyclic steam treatments of wells in the Upper Permian deposit of the Usinskoye field taking into account the influence of geological, production, cost and performance factors. Based on the use of the hydrodynamic model, it was proved that the use of the cyclic steam treatments of wells helps to improve the formation coverage and oil recovery by multiple times. According to the implemented multivariate computations, the best process parameters for the multiple cyclic steam treatments were justified.

We offer the analytical overview of the literature in modeling and optimization of wells CST, the existing 
Table 3 deterioration of well CST efficiency. Therefore, certain

Net present value for the three scenarios

\begin{tabular}{|l|c|}
\hline \multicolumn{1}{|c|}{ Scenario } & $\begin{array}{c}N P V, \\
\text { million RUB }\end{array}$ \\
\hline 1. Baseline without CST & 1.14 \\
\hline 2. CST with basic parameters & 160.01 \\
\hline 3. CST with optimum parameters & 190.53 \\
\hline
\end{tabular}

Table 4

Computation of cost indicators

\begin{tabular}{|l|c|}
\hline \multicolumn{1}{|c|}{ Indicator } & Value \\
\hline Oil in domestic market (including VAT), RUB/t & 14,500 \\
\hline Discount rate, \% & 15 \\
\hline - Income tax, \% & 20 \\
\hline - VAT, \% & 20 \\
\hline - Barrelage tax, RUB/t & 9140 \\
\hline - producing a directional oil well, RUB/m & $71,038.4$ \\
\hline - transition to another horizon, thousand & 5276 \\
RUB/well-operation & 65 \\
\hline US Dollar exchange rate, RUB/Dollar. & \\
\hline
\end{tabular}

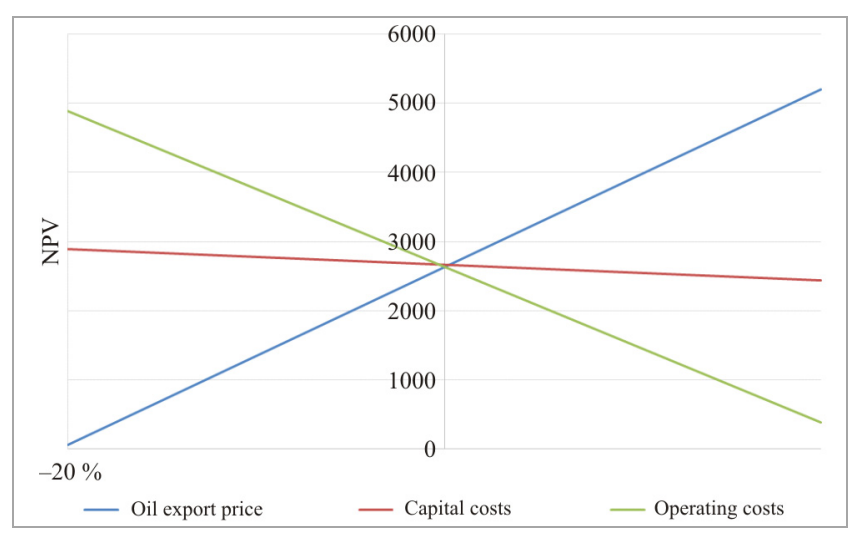

Fig. 9. Sensitivity analysis

well CST models, and the search of the best scenario and specific implementation features.

The geological structure of the field has been described. General characteristics of the field, deposit structure, stratigraphy, tectonics and oil content were provided. Special focus was made on the properties and composition of the produced fluids.

The Upper Permian deposit of the Usinskoye field has been analyzed in terms of its condition by 2019 , with details of oil, gas and water production volumes. The development efficiency has been assessed. We analyzed the geological, engineering measures and reasons of the well's water flooding. The analysis suggests the further growth of the product water cut and recommendations are to be observed in order to increase CST profitability for the wells.

The conclusions section contains an assessment of the cost-performance indicators for the three operation scenarios of the deposit. According to the computations, the development using CST is much more efficient and ensures an additional increment in the cumulative oil production.

According to the cost-performance computations, the implementation of the cyclic steam treatments of the wells in the Upper Permian deposit of the Usinskoye field would help to obtain a higher net present value compared to the well operation with the natural recovery drive.

\section{References}

1. Monitoring razrabotki mestorozhdenii TPP "Usinskneftegaz" [Monitoring of development of deposits of TPP "Usinskneftegaz"]. Perm: PermNIPIneft', 2019.

2. Dopolnenie k tekhnologicheskomu proektu razrabotki Usinskogo neftianogo mestorozhdeniia (bez permo-karbonovoi zalezhi) Respubliki Komi [Addition to the technological project for the development of the Usinsky oil field (without permcarbon deposits) of the Komi Republic]. Perm: PermNIPIneft', 2018.

3. Artemenko A.I., Kashchavtsev V.E., Fatkullin A.A. Parotsiklicheskoe vozdeistvie kak odin iz prioritetov dobychi vysokoviazkoi nefti [Steam cycling as one of priorities of high-viscosity oil recovery]. Neftianoe khoziaistvo, 2005, no. 6, pp. 113-115.

4. Surguchev M.L. Vtorichnye i tretichnye metody uvelicheniia nefteotdachi plastov [Secondary and tertiary reservoir recovery techniques]. Moscow: Nedra, 1985, 308 p.

5. Umetbaev V.G. Geologo-tekhnicheskie meropriiatiia pri ekspluatatsii skvazhin: spravochnik rabochego [Geological and technical measures for the operation of wells: a reference manual]. Moscow: Nedra, 1989, 215 p.

6. Poryvaeva E.R., Emel'ianov A.V. Sovershenstvovanie tekhnologii parotsiklicheskogo vozdeistviia na prizaboinuiu zonu plasta [Improvement in tecniques of "huff-and-puff" of bottomhole formation zone]. Neftegazovoe delo, 2010, no. 2, pp. 59-63.

7. Sokoliuk L.N., Filimonova L.N. Tekhnologiia vybora skvazhin dlia parotsiklicheskoi obrabotki na mestorozhdeniiakh vysokoviazkoi nefti [Technology of wells selection to be subject to cyclic steam treatment at high-viscous oil fields]. Neftepromyslovoe delo, 2013, no. 11, pp. 65-68. 
8. Malofeev G.E. O mekhanizme pritoka nefti pri paroteplovoi obrabotke skvazhin [On the mechanism of oil inflow during steam and heat treatment of wells]. Neftianoe khoziaistvo, 1986, no. 6 , p. $38-40$.

9. Chuprov I.F. Teoreticheskie i tekhnologicheskie osnovy teplovogo vozdeistviia na zalezhi anomal'no viazkikh neftei i bitumov [Theoretical and technological foundations of thermal effects on deposits of abnormally viscous oils and bitumen]. Ph. D. thesis. Ukhta, 2009, 67 p.

10. Shevelev A.P. Matematicheskoe modelirovanie tsiklicheskogo teplovogo vozdeistviia na neftianye plasty [Mathematical modeling of the cyclic thermal treatment of oil reservoirs]. Ph. D. thesis. Tiumen', 2005, pp. 72-75.

11. Darishchev V.I., Bugaev K.A., Volkov D.A., Blokhin G.A. K voprosu opredeleniia optimal'nykh parametrov parogazovoi smesi pri parogazovoi obrabotke prizaboinoi zony plasta [Some aspects of determination of optimal parameters of steam-gas mixture during steam-gas treatment of a formation bottom area]. Neftepromyslovoe delo, 2012, no. 10, pp. 15-17.

12. Antoniadi D.G. Uvelichenie nefteotdachi plastov gazovymi i parogazovymi metodami [Enhanced oil recovery by gas and gas-vapor methods]. Moscow, 1998, 304 p.

13. Mukhametshin V.Sh., Gutorov A.Iu. K voprosu o vozmozhnosti otsenki stepeni riska obosnovannogo vybora ob"ektov obrabotki prizaboinoi zony plasta metodom termogazobarovozdeistviia [To the question of the possibility of assessing the degree of risk of a reasonable choice of treatment facilities for the bottomhole formation zone by the method of gas and gas]. Neftepromyslovoe delo, 2008, no. 8, pp. 28-29.

14. Nikitin A.Iu., Mitrofanov A.D., Pasynkov A.G., Komarov V.S., Bodriagin A.V. Effektivnost' obrabotki prizaboinoi zony plasta kompleksnymi kislotnymi sostavami $\mathrm{s}$ primeneniem gidrovibrovozdeistviia na mestorozhdeniiakh OOO "RN-IuGANSKNEFTEGAZ" [Efficiency of treatment of the bottom-hole formation zone with complex acid compositions using hydrovibrational action at the fields of RN-YUGANSKNEFTEGAZ LLC]. Neftepromyslovoe delo, 2008, no. 8, pp. 35-38.

15. Hong K.S., Jonsen R.B. Optimization of Multicycle Steam Stimulation. Society of Petroleum Engineers Journal, 1969, vol. 9, iss. 03.

16. Dubiv I.B. Issledovanie i obosnovanie tekhnologii razrabotki slozhnopostroennykh zalezhei vysokoviazkoi nefti (na primere Tazovskogo mestorozhdeniia) [Research and justification of technologies for the development of complex deposits of highly viscous oil (on the example of the Tazovsky field)]. Abstract of Ph. D. thesis. Tiumen', 2013.

17. Vladimirov I.V., Pichugin O.N., Gorshkov A.V. Opyt primeneniia tekhnologii nestatsionarnogo zavodneniia na zalezhakh vysokoviazkoi nefti mestorozhdeniia Severnye Buzachi [Experience in the application of non-stationary waterflooding technologies in high-viscosity oil deposits of the North Buzachi field]. Neftepromyslovoe delo, 2009, no. 7, pp. 35-38.

18. Khisamov R.S., Khuzin R.R., Andreev V.E., Dubinskii G.S. Perspektivy uvelicheniia effektivnosti razrabotki zalezhi vysokoviazkoi nefti s primeneniem energoresursosberegaiushchikh technologii [Prospects of increase in efficiency of development of reservoirs containing highviscosity oil with the use of energy-saving and resource-saving technologies]. Neftianoe khoziaistvo, 2011, no. 9, pp. 45-48.

19. Zakirov I.S., Zaripov A.T., Zakharova E.F., Shaikhutdinov D.K., Bisenova A.A., Beloshapka I.E. Sovershenstvovanie tekhnologii parotsiklicheskoi obrabotki skvazhin s ploshchadnym primeneniem rastvoritelia [Improving the technology of huff-andpuff well treatment with areal solvent application]. Neftianoe khoziaistvo, 2019, no. 9, pp. 45-48.

20. Konoplev Iu.P., Ruzin L.M., Tiun'kin B.A., Litovets K.I., Grutskii L.G., Pitirimov V.V., Pranovich A.A. Primenenie parotsiklicheskogo vozdeistviia na shakhtnykh poliakh Iaregskogo mestorzhdeniia [The use of steam cyclic effects in the mine fields of the Yarega field]. Neftianoe khoziaistvo, 2001, no. 1, pp. 14-18.

21. Ibatullin R.R., Nasybullin A.V., Salimov O.V. Raschet vozmozhnosti gidravlicheskogo razryva pokryshki pri parotsiklicheskom vozdeistvii na Ashal'chinskom mestorozhdenii prirodnykh bitumov [Evaluating feasibility of cap rock fracturing during cyclic steam stimulation at the Ashalchinskoye natural bitumen field]. Neftianoe khoziaistvo, 2011, no. 4, pp. 44-48.

22. Artemenko A.I., Kashchavtsev V.E., Fatkullin A.A. Parotsiklicheskoe vozdeistvie kak odin iz prioritetov dobychi vysokoviazkoi nefti [Steam cycling as one of priorities of high-viscosity oil recovery]. Neftianoe khoziaistvo, 2015, no 6, pp. 42-46.

23. Taraskin E.N., Zakharian A.Z., Ursegov S.O. Adaptivnyi variant otsenki tekhnologicheskoi effektivnosti zakachki para $\mathrm{v}$ usloviiakh karbonatnogo kollektora s vysokoviazkoi neft'iu [Adaptive option of steam injection technological efficiency evaluation for carbonate high-viscosity oil reservoir conditions]. Neftianoe khoziaistvo, 2018, no. 11 , pp. 31-35. 
24. Khisamov R.S., Zakharova E.F., Gumerova D.M., Saiakhov V.A. Kompleksnye issledovaniia sostava i svoistv bituminoznoi nefti Ashal'chinskogo mestorozhdeniia [An integrated approach to the research of the composition and properties of bituminous oil at the Ashalchinskoye field]. Neftianoe khoziaistvo, 2018, no. 9, pp. 34-38.

25. Osipov A.V., Esaulov A.O., Ibragimova M.V., Terent'ev V.L., Petrashov O.V., Azimov T.A. Rezul'taty opytno-promyshlennykh rabot po paroteplovomu vozdeistviiu na treshchinovatye karbonatnye plasty so sverkhviazkoi neft'iu na mestorozhdenii Boka de Kharuko [The results of pilot steam stimulations of heavy oil saturated fractured carbonate reservoir, Boca de Haruko field]. Neftianoe khoziaistvo, 2018, no. 9, pp. 39-42.

26. Kudinov V.I. Novye tekhnologii povysheniia nefteotdachi na mestorozhdeniiakh s vysokoviazkimi neftiami [New oil recovery enhancement technologies for high-viscosity oil fields]. Neftianoe khoziaistvo, 2002, no. 5, pp. 31-36.

27. Solomatin A.G., Grishin P.A., Osipov A.V., Azimov T.A., Petrashov O.V. Rezul'taty opytnykh rabot po teplovomu vozdeistviiu na karbonatnyi plast, nasyshchennyi tiazheloi neft'iu [The results of pilot works on thermal treatment at carbonate heavy oil reservoir]. Neftianoe khoziaistvo, 2016, no. 12 , pp. 118-121.

28. Taraskin E.N., Simakov Ia.O. Rezul'taty avtomatizirovannoi adaptatsii gidrodinamicheskoi modeli uchastka opytno-promyshlennykh rabot permo-karbonovoi zalezhi Usinskogo mestorozhdeniia [The results of the automated hystory matching of the pilot area thermo-hydrodynamic model of the Permian-Carboniferous reservoir of the Usinskoye field]. Neftianoe khoziaistvo, 2015, no. 12 , pp. 110-114.

29. Ruzin L.M., Moroziuk O.A., Durkin S.M. Osobennosti i innovatsionnye napravleniia osvoeniia resursov vysokoviazkikh neftei [Features and innovative ways of highly viscous oil field development]. Neftianoe khoziaistvo, 2013, no. 8 , pp. $45-48$.

30. Khisamov R.S., Zaripov A.T., Ibatullina S.I. Analiz vliianiia uplotniaiushchego bureniia na effektivnost' razrabotki mestorozhdenii sverkhviazkoi nefti pri parogravitatsionnom vozdeistvii [Effect of infill drilling on heavy oil reservoir performance in steam-gravity recovery projects]. Neftianoe khoziaistvo, 2013, no. 7, pp. 33-38.

31. Ruzin L.M. Innovatsionnye napravleniia razrabotki zalezhei vysokoviazkin neftei i bitumov [Innovative lines of high viscosity oil and bitumen deposits development]. Neftianoe khoziaistvo, 2012, no. 1, pp. 31-36.
32. Shkandratov V.V., Burakova S.V., Ursegov S.O., Tarasov G.A. Bazovye printsipy, effektivnost' i osnovnye perspektivy razrabotki permo-karbonovoi zalezhi Usinskogo mestorozhdeniia [Base principles, efficiency and primary prospects for development of Permo-Carbon pool of Usinskoye oil field]. Neftianoe khoziaistvo, 2007, no. 8, pp. 56-60.

33. Akhunov R.M., Gareev R.Z., Abdulkhairov R.M., Iangurazova Z.A. Probnaia ekspluatatsiia gorizontal'nykh skvazhin s paroteplovym vozdeistviem na plast [Horizontal wells trial operation with thermal-steam formation treatment]. Neftianoe khoziaistvo, 2005, no. 11, pp. $46-49$.

34. Ruzin L.M., Ursegov S.O. Razvitie teplovykh metodov razrabotki permo-karbonovoi zalezhi Usinskogo mestorozhdeniia [Elaboration of thermal methods of developme of Permian-Carbon reservoir of Usinskoye oilfii]. Neftianoe khoziaistvo, 2005, no. 02 , pp. $43-47$.

35. Hamoodi A.N., Abed A.F., Firoozabadi A. Compositional modelling of two-phase hydrocarbon reservoirs. Petroleum Society of Canada. DOI: 0.2118/01-04-03

36. Coutinho R., Williams W., Waltrich P., Mehdizadeh P., Scott S. A model for liquidassisted gaslift unloading. Conference Paper 18th International Conference on Multiphase Production Technology. Cannes, 2017, BHR-2017-345R.

37. Mehana M., Fahes M., Huang L. The density of oil / gas mixtures: insights from molecular simulations. Society of Petroleum Engineers. DOI: $10.2118 / 187297-P A$

38. Bailey R.E. et al. Enhanced oil recovery. Natl. Petroleum Council, Industry Advisory Committee to the U.S. Washington, 1984.

39. Digital solutions for the mining industry, available at: https://new.siemens.com/global/en/ markets/ mining-industry/digitalization.html (accessed 23 April 2019).

40. Dassault Systèmes aids coal mining reporting with release of GEOVIA Minex 6.5, available at: http://www.mining.com/web/dassault-systemes-aidscoal-mining-reporting-with-release-of-geovia-minex-65/ (accessed 23 April 2019).

41. Altunina L.K., Kuvshinov V.A., Kuvshinov I.V., Stasyeva L.A., Chertenkov M.V., Shkrabyuk L.S., Andreev D.V. Physical-chemical and complex EOR/IOR technologies for the Permian-Carboniferous deposit of heavy oil of the Usinskoye oil field. Oil Industry Journal, 2017, no. 07, pp. 26-29. DOI: 10.24887/0028-2448-2017-7-26-29

42. Alireza Emadi. Enhanced heavy oil recovery by water and carbon dioxide flood: Submitted for the Degree of Doctoral of Philosophy in Petroleum Engineering. Edinburgh, 2012, 340 p. 
43. Luo P., Erl V., Freitag N., Huang S. Recharacterizing evolving fluid and PVT properties of Weyburn oil- $\mathrm{CO}_{2}$ system. International Journal of Greenhouse Gas Control, 2013, no. 16, pp. 226-235. DOI: 10.1016/j.ijggc.2013.03.001

44. Bryant D.W., Monger T.G. Multiple-contact phase behavior measurement and application with mixtures of $\mathrm{CO}_{2}$ and highly asphaltic crude. SPE Reservoir Engineering, 1988, vol. 3, no. 2, pp. 701-710.

45. V. Parasiliti Parracello, Bartosek M., M. De Simoni, Mallardo C. Experimental evaluation of $\mathrm{CO}_{2}$ injection in a heavy oil reservoir. International Petroleum Technology Conference held in Bangkok, 7-9 February. Bongkok, 2012.

46. Chung F.T.H., Ray A.J., Hal T.N. Measurements and correlations of the physical properties of $\mathrm{CO}_{2} /$ heavy-crude-oil mixtures. SPE Journal, 1988, vol. 3, no. 3, pp. 822-828. DOI: 10.2118/15080-PA

\section{Библиографический список}

1. Мониторинг разработки месторождений ТПП «Усинскнефтегаз». - Пермь: Изд-во ПермНИПИнефть, 2019.

2. Дополнение к технологическому проекту разработки Усинского нефтяного месторождения (без пермо-карбоновой залежи) Республики Коми. Пермь: Изд-во ПермНИПИнефть, 2018.

3. Артеменко А.И., Кащавцев В.Е., Фаткуллин А.А. Пароциклическое воздействие как один из приоритетов добычи высоковязкой нефти // Нефтяное хозяйство. - 2005. - № 6. - С. 113-115.

4. Сургучев М.Л. Вторичные и третичные методы увеличения нефтеотдачи пластов. М.: Недра, 1985. - 308 с.

5. Уметбаев В.Г. Геолого-технические мероприятия при эксплуатации скважин: справочник рабочего. - М.: Недра, 1989. - 215 с.

6. Порываева Э.Р., Емельянов А.В. Совершенствование технологии пароциклического воздействия на призабойную зону пласта // Нефтегазовое дело. - 2010. - № 2. - С. 59-63.

7. Соколюк Л.Н., Филимонова Л.Н.. Технология выбора скважин для пароциклической обработки на месторождениях высоковязкой нефти // Нефтепромысловое дело. - 2013. - № 11. - С. 65-68.

8. Малофеев Г.Е. О механизме притока нефти при паротепловой обработке скважин // Нефтяное хозяйство. -1986 . - № 6. - С. 38-40.

9. Чупров И.Ф. Теоретические и технологические основы теплового воздействия на залежи аномально вязких нефтей и битумов: дис. ... д-ра техн. наук. - Ухта, 2009. - С. 67.
10. Шевелев А.П. Математическое моделирование циклического теплового воздействия на нефтяные пласты: дис. ... канд. физ.-мат. наук. Тюмень, 2005. - С. 72-75.

11. К вопросу определения оптимальных параметров парогазовой смеси при парогазовой обработке призабойной зоны пласта / В.И. Дарищев, К.А. Бугаев, Д.А. Волков, Г.А. Блохин // Нефтепромысловое дело. - 2012. - № 10. - С. 15-17.

12. Антониади Д.Г. Увеличение нефтеотдачи пластов газовыми и парогазовыми методами. M., 1998. - 304 c.

13. Мухаметшин В.Ш., Гуторов А.Ю. К вопросу о возможности оценки степени риска обоснованного выбора объектов обработки призабойной зоны пласта методом термогазобаровоздействия // Нефтепромысловое дело. 2008. - № 8. - C. 28-29.

14. Эффективность обработки призабойной зоны пласта комплексными кислотными составами с применением гидровибровоздействия на месторождениях ООО «РН-ЮГАНСКНЕФТЕГАЗ» / А.Ю. Никитин, А.Д. Митрофанов, А.Г. Пасынков, В.С. Комаров, А.В. Бодрягин // Нефтепромысловое дело. - 2008. - № 8. - С. 35-38.

15. Hong K.S., Jonsen R.B. Optimization of multicycle steam stimulation // Society of Petroleum Engineers Journal. - 1969. - Vol. 9, iss. 03.

16. Дубив И.Б. Исследование и обоснование технологий разработки сложнопостроенных залежей высоковязкой нефти (на примере Тазовского месторождения): автореф. дис. .... канд. техн. наук. - Тюмень, 2013.

17. Владимиров И.В., Пичугин О.Н., Горшков А.В. Опыт применения технологий нестационарного заводнения на залежах высоковязкой нефти месторождения Северные Бузачи // Нефтепромысловое дело. - 2009. - № 7. - С. 35-38.

18. Перспективы увеличения эффективности разработки залежи высоковязкой нефти с применением энергоресурсосберегающих технологий / Р.С. Хисамов, Р.Р. Хузин, В.Е. Андреев, Г.С. Дубинский // Нефтяное хозяйство. - 2011. - № 9. C. 45-48.

19. Совершенствование технологии пароциклической обработки скважин с площадным применением растворителя / И.С. Закиров, А.Т. Зарипов, Е.Ф. Захарова, Д.К. Шайхутдинов, А.А. Бисенова, И.Е. Белошапка // Нефтяное хозяйство. -2019 . - № 9. - С. 45-48.

20. Применение пароциклического воздействия на шахтных полях Ярегского месторждения / Ю.П. Коноплев, Л.М. Рузин, Б.А. Тюнькин, К.И. Литовец, Л.Г. Груцкий, В.В. Питиримов, А.А. Пранович // Нефтяное хозяйство. - 2001. - № 1. - С. 14-18. 
21. Ибатуллин Р.Р., Насыбуллин А.В., Салимов О.В. Расчет возможности гидравлического разрыва покрышки при пароциклическом воздействии на Ашальчинском месторождении природных битумов // Нефтяное хозяйство. - 2011. - № 4. С. $44-48$.

22. Артеменко А.И., Кащавцев В.Е., Фаткуллин А.А. Пароциклическое воздействие как один из приоритетов добычи высоковязкой нефти // Нефтяное хозяйство. - 2015. - № 6. - С. 42-46.

23. Тараскин Е.Н., Захарян А.З., Урсегов С.О. Адаптивный вариант оценки технологической эффективности закачки пара в условиях карбонатного коллектора с высоковязкой нефтью // Нефтяное хозяйство. - 2018 . - № 11. C. 31-35.

24. Комплексные исследования состава и свойств битуминозной нефти Ашальчинского месторождения / Р.С. Хисамов, Е.Ф. Захарова, Д.М. Гумерова, В.А. Саяхов // Нефтяное хозяйство. 2018. - № 9. - С. 34-38.

25. Результаты опытно-промышленных работ по паротепловому воздействию на трещиноватые карбонатные пласты со сверхвязкой нефтью на месторождении Бока де Харуко / А.В. Осипов, А.О. Есаулов, М.В. Ибрагимова, В.Л. Терентьев, О.В. Петрашов, Т.А. Азимов // Нефтяное хозяйство. 2018. - № 9. - С. 39-42.

26. Кудинов В.И. Новые технологии повышения нефтеотдачи на месторождениях с высоковязкими нефтями // Нефтяное хозяйство. 2002. - № 5. - С. 31-36.

27. Результаты опытных работ по тепловому воздействию на карбонатный пласт, насыщенный тяжелой нефтью / А.Г. Соломатин, П.А. Гришин, А.В. Осипов, Т.А. Азимов, О.В. Петрашов // Нефтяное хозяйство. - 2016 . - № 12. C. $118-121$.

28. Тараскин Е.Н., Симаков Я.О. Результаты автоматизированной адаптации гидродинамической модели участка опытно-промышленных работ пермо-карбоновой залежи Усинского месторождения // Нефтяное хозяйство. - 2015 - № 12. C. $110-114$.

29. Рузин Л.М., Морозюк О.А., Дуркин С.М. Особенности и инновационные направления освоения ресурсов высоковязких нефтей // Нефтяное хозяйство. - 2013. - № 8. C. $45-48$.

30. Анализ влияния уплотняющего бурения на эффективность разработки месторождений сверхвязкой нефти при парогравитационном воздействии / Р.С. Хисамов, А.Т. Зарипов, С.И. Ибатуллина // Нефтяное хозяйство. - 2013. № 7. - С. 33-38.
31. Рузин Л.М. Инновационные направления разработки залежей высоковязкин нефтей и битумов // Нефтяное хозяйство. - 2012. - № 1. C. $31-36$.

32. Базовые принципы, эффективность и основные перспективы разработки пермокарбоновой залежи Усинского месторождения / В.В. Шкандратов, С.В. Буракова, С.О. Урсегов, Г.А. Тарасов // Нефтяное хозяйство. - 2007. № 8. - C. 56-60.

33. Пробная эксплуатация горизонтальных скважин с паротепловым воздействием на пласт / P.М. Ахунов, Р.3. Гареев, Р.М. Абдулхаиров, 3.А. Янгуразова // Нефтяное хозяйство. - 2005. № 11. - C. 46-49.

34. Рузин Л.М., Урсегов С.О. Развитие тепловых методов разработки пермо-карбоновой залежи Усинского месторождения // Нефтяное хозяйство. -2005 . - № 02. - С. 43-47.

35. Hamoodi A.N., Abed A.F., Firoozabadi A. Compositional modelling of two-phase hydrocarbon reservoirs / Petroleum Society of Canada. DOI: 0.2118/01-04-03

36. A model for liquidassisted gas-lift unloading / R. Coutinho, W. Williams, P. Waltrich, P. Mehdizadeh, S. Scott // Conference Paper 18th International Conference on Multiphase Production Technology. Cannes, 2017. - BHR-2017-345R.

37. Mehana M., Fahes M., Huang L. The density of oil/gas mixtures: insights from molecular simulations // Society of Petroleum Engineers. - 2018. - Vol. 23, № 5. - P. 1798-1808. DOI: 10.2118/187297-PA

38. Enhanced oil recovery / R.E. Bailey [et al.] // Natl. Petroleum Council, Industry Advisory Committee to the U.S. - Washington, 1984.

39. Digital solutions for the mining industry [Электронный pecypc]. - URL: https://new.siemens. com/global/en/markets/mining-industry/digitalization.html (дата обращения: 23.04.2019).

40. Dassault systèmes aids coal mining reporting with release of GEOVIA Minex 6.5 [Электронный pecypc]. - URL: http://www.mining.com/web/dassaultsystemes-aids-coal-mining-reporting-with-release-ofgeovia-minex-6-5/ (дата обращения: 23.04.2019).

41. Physical-chemical and complex EOR/IOR technologies for the Permian-Carboniferous deposit of heavy oil of the Usinskoye oil field / L.K. Altunina, V.A. Kuvshinov, I.V. Kuvshinov, L.A. Stasyeva, M.V. Chertenkov, L.S. Shkrabyuk, D.V. Andreev // Oil Industry Journal. - 2017. - № 07. - C. 26-29. DOI: $10.24887 / 0028-2448-2017-7-26-29$

42. Alireza Emadi. Enhanced heavy oil recovery by water and carbon dioxide flood: submitted for the degree of doctoral of philosophy in petroleum engineering. - Edinburgh, 2012. -340 p. 
43. Recharacterizing evolving fluid and PVT properties of weyburn oil- $\mathrm{CO}_{2}$ system / P. Luo, V. Erl, N. Freitag, S. Huang // International Journal of Greenhouse Gas Control. - 2013. - № 16. P. 226-235. DOI: 10.1016/j.ijggc.2013.03.001

44. Bryant D.W., Monger T.G. Multiple-contact phase behavior measurement and application with mixtures of $\mathrm{CO}_{2}$ and highly asphaltic crude // SPE Reservoir Engineering. - 1988. - Vol. 3, № 2. P. 701-710.
45. Experimental evaluation of $\mathrm{CO}_{2}$ injection in a heavy oil reservoir / V. Parasiliti Parracello, M. Bartosek, M. De Simoni, C. Mallardo // International Petroleum Technology Conference held in Bangkok, 7-9 February. - Bangkok, 2012.

46. Chung F.T.H., Ray A.J., Hal T.N. Measurements and correlations of the physical properties of $\mathrm{CO}_{2}$ /heavy-crude-oil mixtures // SPE Journal. - 1988. - Vol. 3, № 3. - P. 822-828. DOI: $10.2118 / 15080-P A$.

Please cite this article in English as:

Savchik M.B., Ganeeva D.V., Raspopov A.V. Improvement of the efficiency of cyclic steam stimulation of wells in the upper Permian deposit of the Usinskoye field based on the hydrodynamic model. Perm Journal of Petroleum and Mining Engineering, 2020, vol.20, no.2, pp.137-149. DOI: 10.15593/2224-9923/2020.2.4

Просьба ссылаться на эту статью в русскоязычных источниках следующим образом:

Савчик М.Б., Ганеева Д.В., Распопов А.В. Повышение эффективности пароциклических обработок скважин Верхнепермской залежи Усинского месторождения на основе гидродинамической модели // Вестник Пермского национального исследовательского политехнического университета. Геология. Нефтегазовое и горное дело. - 2020. T.20, №2. - C.137-149. DOI: 10.15593/2224-9923/2020.2.4 